\title{
Antibodies against Toxoplasma gondii in horses from the coastal and mountain mesoregions of the state of Santa Catarina, Brazil
}

\section{Anticorpos contra Toxoplasma gondii em equinos das mesorregiões serrana e litorânea de Santa Catarina, Brasil}

\author{
Anderson Barbosa de Moura $^{1 *}$; João Pedro Matiello²; Marcio Orides da Silva ${ }^{3}$; \\ Antonio Pereira de Souza ${ }^{4}$; Amélia Aparecida Sartor ${ }^{1}$
}

\begin{abstract}
Toxoplasmosis is a zoonotic disease caused by the protozoan Toxoplasma gondii. Among domestic species, the horse is one of those most resistant to T. gondii infection; however, upon acute infection, horses may present hyperirritability, poor motor coordination, ocular disorders, and abortion. Herein, we investigated the presence of antibodies against $T$. gondii, in order to identify possible risk factors for infection in horses and to establish the correlation of $T$. gondii infection with reproductive and/ or neurological disorders. We collected 615 blood samples from animals in the mountain mesoregion $(n=311)$ and the coastal mesoregion $(n=304)$ of Santa Catarina state. An epidemiological questionnaire was used to identify possible risk factors. Antibodies to $T$. gondii were detected by immuno-fluorescence assay (IFA $\geq 1$ :64) using RH strain tachyzoites of the protozoan as antigen. Correlation $(\mathrm{P}<0.05)$ between seropositivity and race, sex, age, diet, contact with other animals, reproductive and/or neurological disorders, and origin were assessed. The overall incidence of seropositivity was $10.4 \%(64 / 615)$, and in the mountain and coastal regions, $10.3 \%$ and $10.5 \%$, respectively. The reciprocal of the titles observed was: 1:64 (36), 1:256 (26) and 1:1024 (two). There was no significant difference ( $\mathrm{P}>0.05)$ between regions, and there was no correlation between seropositivity and the variables analyzed.
\end{abstract}

Key words: Horse, immuno-fluorescence assay (IFA), Santa Catarina, Toxoplasma gondii

\section{Resumo}

A toxoplasmose é uma zoonose parasitária, causada pelo protozoário Toxoplasma gondii. Os equinos estão entre as espécies domésticas mais resistentes à infecção, porém, em infecções agudas, podem apresentar sintomas como hiperirritabilidade, incoordenação motora, distúrbios oculares e aborto. Com os objetivos de determinar a ocorrência de anticorpos contra $T$. gondii, identificar possíveis fatores de risco para a infecção em cavalos e a correlação da infecção toxoplásmica com distúrbios reprodutivos e/ou neurológicos, em animais de duas mesorregiões do estado de Santa Catarina (Serrana e Litorânea), 615 amostras de sangue (311 provenientes da região serrana e 304 do litoral) foram colhidas. Um questionário epidemiológico foi aplicado para a identificação de possíveis fatores de risco. A pesquisa de anticorpos foi realizada por meio da Reação de Imunofluorescência Indireta (RIFI $\geq 1: 64$ ) utilizando como antígeno taquizoítos da cepa RH do protozoário. Os dados foram analisados pelos testes exato de Fischer e do $\chi^{2}$ para verificar correlação $(\mathrm{P}<0,05)$ entre soropositividade e as variáveis analisadas (Raça; Sexo; Idade; Dieta Principal; Contato com outros animais; Desordens reprodutivas e/ou neurológicas e

${ }^{1}$ Profs. Associados, Dept ${ }^{\circ}$ de Medicina Veterinária, DMV, Centro de Ciências Agroveterinárias, CAV, Universidade do Estado de Santa Catarina, UDESC, Lages, SC, Brasil.E-mail: anderson.moura@udesc.br; amelia.sartor@udesc.br

2 Discente do Curso de Graduação em Medicina Veterinária, CAV, UDESC, Lages, SC, Brasil. E-mail: jpdro_matiello@hotmail.com

${ }^{3}$ Discente do Curso de Mestrado do Programa de Pós-Graduação em Ciência Animal, CAV, UDESC, Lages, SC, Brasil. E-mail: marcioorides@hotmail.com

4 Prof. Visitante Sênior, Instituto Federal Catarinense, IFC, Campus de Araquari, Bolsista PVNS/CAPES, e Prof. Voluntário Programa de Pós-graduação em Ciência Animal, UDESC, Lages, SC, Brasil. E-mail: antonio.souza@ifc-araquari.edu.br

* Author for correspondence 
procedência). A ocorrência geral de animais positivos foi de 10,4\% (64/615), com as regiões Serrana e Litorânea apresentando $10,3 \%$ e $10,5 \%$ de animais positivos, respectivamente. A recíproca dos títulos observada foi: 1:64 (36), 1:256 (26) e 1:1024 (2). Não foi observada diferença ( $\mathrm{P}>0,05)$ entre as regiões e nem correlação entre a soropositividade e as variáveis analisadas.

Palavras-chave: Equinos, RIFI, Santa Catarina, Toxoplasma gondii

\section{Introduction}

Toxoplasma gondii usually infects its host without producing clinical signs, but it can cause severe illness, particularly congenital infection, in immune-compromised individuals. Among animals intended for human consumption, pigs, sheep, and goats are more frequently infected than horses and cattle (DUBEY; THULLIEZ, 1993). Herbivores acquire infection mainly by ingesting food, grass, or animal feed contaminated with oocysts.

Toxoplasmosis in horses in Brazil was first reported in 1975 (MACRUZ et al., 1975). The authors reported aborted fetuses, of 5- to 6-months gestation, with hepatitis lesions and the presence of T. gondii pseudocysts. In contrast, the results of a study by Marques et al. (1998) in pregnant mares experimentally infected with oocysts of the parasite suggested that $T$. gondii should not be considered as a possible etiologic agent responsible for abortions in mares.

Cultural and dietary habits are important factors influencing $T$. gondii infection (TENTER et al., 2000). The consumption of horse meat may pose a risk to human health in regions where this diet is customary (DUBEY; DESMONTES, 1987). The parasite has been isolated from the muscle tissue of healthy horses (AL-KHALIDI; DUBEY, 1979). Pomares et al. (2011), reported that consumption of raw or undercooked horse meat in order to strengthen immunity, especially in pregnant women, favored human infection.

According to the Brazilian Ministry of Agriculture, Livestock, and Food Supply (BRASIL, 2013), this country has the largest population of horses in Latin America and the third-largest population in the world. Horses, donkeys, and mules together totaled eight million animals.
The slaughter of horses as well as the packaging and distribution of horse meat is legal in Brazil, under the proviso that this type of meat be so labeled (JUNQUEIRA et al., 2005). Brazil has become the world's eighth largest horse meat exporter, usually of unwanted horses (CASTAGNO, 2013); the largest importers of Brazilian products are Belgium, Italy, Japan, and France (BRASIL, 2013). Among horses designated for slaughter from six Brazilian states, $11.6 \%$ of the animals were seropositive (IFA 264) for T. gondii (EVERS et al., 2013).

In France, T. gondii infection was described in a pregnant patient who had consumed horsemeat. Genotypic characterization showed that the mother was infected with a strain different to that commonly found in Europe, while the strain isolated from the fetus was commonly found in South America (ELBEZ-RUBENSTEIN et al., 2009).

Pomares et al. (2011), in France, described three cases of toxoplasmosis, probably acquired by ingestion of raw horse meat. Two of the three patients were pregnant women who had been found to be infected with $T$. gondii during prenatal examinations. The genotyping of $T$. gondii and epidemiological analysis revealed the origin of the meat consumed by two of the three patients (one had consumed meat imported from Canada and the other meat imported from Brazil).

Human toxoplasmosis cases associated with horse meat consumption are rarely reported and are probably underestimated. Furthermore, recently, cases of adulteration of beef with horse meat have been reported in Europe (LOPES et al., 2013). In the European Union, France and Italy account for more than two-thirds of all horse meat eaten, predominantly raw, thereby increasing the likelihood of infection by various parasites, including $T$. gondii (ELBEZ-RUBENSTEIN et al., 2009). 
Studies of the prevalence of $T$. gondii antibodies in horses from different countries, including Brazil, vary from $0 \%$ to $80 \%$. Such results can be influenced by the sensitivity of the tests used, the age of the animals, the geographic region, and animal handling (TASSI, 2007).

There have been some studies of infection of horses by $T$. gondii in Brazil, but no such surveys have yet been performed in the state of Santa Catarina.

\section{Materials and Methods}

From August 2012 to December 2013, 615 blood samples were obtained from horses (311 from the mountain and 304 from the coastal region of Santa Catarina; Table 1) and the sera were stored at $-20^{\circ} \mathrm{C}$ until the completion of IFA for the detection of antibodies to T. gondii. Among the 615 horses (270 male and 345 female), four were in the age group of $\leq$ 6-months-old, 11 were 6- to 12-months-old, 197 were 1 - to 5-years-old, 227 were 6- to 10-years-old, and 176 were $>10$-years-old. The animals were randomly selected, without inclusion or exclusion criteria, and all the animals were clinically healthy at the time of blood collection. No other information was available. In total, 92 groups/farms, highly heterogeneous, were represented, including animals from urban (carters, military police) and rural (farm animals) areas.

Table 1. Cities, number of properties and horses sampled for search of Toxoplasma gondii antibodies from the Mountain and Coastal regions, Santa Catarina State, Brazil. 2013.

\begin{tabular}{|c|c|c|}
\hline City & Famrs (n) & Animals (n) \\
\hline Barra velha & 01 & 09 \\
\hline Brusque & 02 & 20 \\
\hline Camboriú & 09 & 24 \\
\hline Capão Alto & 02 & 20 \\
\hline Chapecó & 03 & 15 \\
\hline Itajaí & 04 & 19 \\
\hline Itapema & 01 & 09 \\
\hline Lages & 12 & 194 \\
\hline Laguna & 01 & 20 \\
\hline Lauro Muller & 03 & 14 \\
\hline Orleans & 04 & 15 \\
\hline Otacílio Costa & 02 & 18 \\
\hline Painel & 02 & 17 \\
\hline Santa Cecília & 01 & 22 \\
\hline São Ludgero & 03 & 06 \\
\hline São João do Sul & 01 & 66 \\
\hline São José do Cerrito & 01 & 22 \\
\hline Tijucas & 02 & 07 \\
\hline Tubarão & 03 & 05 \\
\hline Urussanga & 03 & 08 \\
\hline Total & 60 & 615 \\
\hline
\end{tabular}


The horse herd in the state of Santa Catarina comprises 122,565 animals, with 32,450 living in the mountain mesoregion and 32,645 on the coast (mesoregions Vale do Itajaí and Florianópolis) (IBGE, 2012), representing $53.11 \%$ of the equine population of the state. We sampled 615 randomly selected horses, resulting in an expected prevalence of $15 \%$, error of $5.0 \%$, and a confidence level of 99\% (OPAS, 1979).

IFA tests were performed as previously described by Camargo (1974), with a cut-off point of 64. Positive samples were serially diluted in four-fold, to titrate the maximum reactive dilution. Positive and negative control serums were used for comparison.

Information about the animals was obtained through a questionnaire (as an Informed Consent Statement) given to the owners on the day of blood collection; the questions were related to the methods of animal handling, frequency and type of reproductive and/or neurological disorders, contact with cats and/or other animals, sex, age, race, and origin.

Data were tabulated and statistically analyzed (Fischer's exact and chi-square tests) to assess the correlation between the results of serology and the variables analyzed.

This project was approved by the Animal Experimentation Ethics Committee of CAV/UDESC (Protocol 1.05.09) and by the Ethics Committee on Research Involving Humans of UDESC (Protocol $73 / 09$ on 10.08 .09 ).

\section{Results and Discussion}

The overall occurrence of antibodies against $T$. gondii in horses was $10.4 \%(64 / 615)$ in this study. Of the 311 samples in the mountain region, 32 (10.2\%), and of the 304 in the Coastal region, 32 (10.5\%) were positive by IFA. The titers were distributed as follows: 36 had a titer of 64, 26 had a titer of 256 , and two had a titer of 1024 . In almost all groups/ farms analyzed (91/92), at least one infected animal was detected, and in eight of these sources, 100\% of the sampled animals were positive for $T$. gondii.

A cutoff point of 1:64 was used in this study, which ensures greater specificity and decreases the possibility of cross-reactions with other Apicomplexa, such as Hammondia hammondi (MENDONÇA et al., 2001; COIRO et al., 2012). These antibody titers against $T$. gondii (64 [56.3\%], $256[40.7 \%]$, and $1024[3 \%])$ is indicative of infection or a previous exposure of these horses to this organism.

Different methods of diagnosis and cut-offs are used around the world, making it difficult to compare the results of similar reports. Camossi et al. (2010), using IFA and MAT, at a cut-off of 1:16 for both approaches, observed statistically significant differences in the prevalence rates depending on the approach used ranging from $5.9 \%$ for IFA to $12.6 \%$ for MAT.

A few epidemiological studies from other parts of the world, which used methods other than IFA, with a cut-off of 1:64, for diagnosis of toxoplasmosis in horses, have been reported. The seroprevalence obtained in this study was lower than those reported in Nigeria (37.1\% by the indirect hemagglutination test [IHA]), Saudi Arabia (18.4\%; IHA), and southwestern China (30.5\%; IHA) (AGANGA et al., 1983; EBTESAM et al., 2014; MIAO et al., 2013). However, it was higher than that observed in Japan (MATSUO et al., 2014), where 100 animals evaluated by the latex agglutination test (LAT) were all negative, and that observed in China (6.7\%; IHA) (LING; WAN, 1984).

In Brazil, considering only data obtained by IFA ( $\geq 1: 64$ ), the results differed according to the population studied, and was $1.5 \%$ in Bahia (MENDONÇA et al., 2001), 8.3\% in Paraíba (OLIVEIRA FILHO et al., 2012), 12.1\% in Paraná (GARCIA et al., 1999), 17.0\% in the metropolitan region of Curitiba (FINGER et al., 2013), and ranged from $11.6 \%$ to $27.12 \%$ in slaughterhouse 
animals from different states of the country (EVERS et al., 2013; GENNARI et al., 2015). When a cutoff of 1:16 was used for IFA by other authors in Brazil, the observed prevalence rates were higher, varying from $30 \%$ to $32.8 \%$ in Mato Grosso do Sul (LARANJEIRA et al., 1985; VIDOTTO et al., 1997), $41.22 \%$ in Paraná, and $46.75 \%$ in Mato Grosso (VIDOTTO et al., 1997). Gazeta et al. (1997), in Rio de Janeiro, and Vidotto et al. (1997) and Coiro et al. (2012), in São Paulo, found prevalence rates of $4.45 \%, 21.9 \%$, and $5.88 \%$, respectively.

These differences are due to various factors, such as the $T$. gondii strain, feeding, and the water source that is available to the animals (KIJLSTRA; JONGERT, 2009; KOUAM et al., 2010; MENDONÇA et al., 2001). Furthermore, the type of activity performed and the geographic location of the horses may have a significant effect on the development of $T$. gondii infection (FINGER et al., 2013; KOUAM et al., 2010).

In this study no significant differences were found in terms of gender and age (Table 2), supporting the observations of Mendonça et al. (2001) and Camossi et al. (2010). Only one animal younger than 1 year showed a positive reaction, and the majority of the seropositive animals $(98.42 \%)$ were older than 1 year. Of the positive animals, $40.63 \%(26 / 64)$ were aged between 1 and 5 years, $34.37 \%$ were aged between 6 and 10 years, and $23.42 \%$ were older than 10 years.

Environmental conditions, such as rainfall, temperature, or altitude may affect the distribution of $T$. gondii, and thereby infection in a population (AGANGA et al., 1983); however, in this study, we observed no differences in positivity between animals from the mountain or coastal regions of
Santa Catarina state or between the groups/farms evaluated.

Despite the fact that we found no correlation between the $T$. gondii-seropositive animals and contact with other animals, including cats, in the state of Mato Grosso do Sul, Brazil, was reported that seropositive animals were found closer to the houses of the farmers, who owned cats to control the mice population (SILVA, 2005). Cats should be kept away from the facilities, pasture, and water source of horses, as they are the most significant species in the epidemiology of the disease (DUBEY; JONES, 2008). The highest prevalence rates may occur in areas where the equids are in contact with cats near the facilities (DUBEY et al., 1999). Moreover, in our study, there was also no correlation between serology and management, reproductive and/or neurological problems, race, or origin of the horses (Table 2).

Among the positive animals, $89.0 \%$ had no reproductive disorders (Table 2 ) and, although this was a statistically significant correlation $(\mathrm{P}<0.05)$, this was due to sampling, because $88.2 \%$ of the evaluated animals had not exhibited reproductive problems in the last 12 months prior to collection of blood.

The results of this study, the first serological survey for $T$. gondii in horses in the state of Santa Catarina, indicated a relatively low frequency of positive animals. However, the implications of these data cannot be underestimated, since viable $T$. gondii have already been isolated from seropositive horses (EVERS et al., 2013), with even lower titers using the Sabin Feldman dye test (AL-KHALIDI; DUBEY, 1979; DUBEY; DESMONTS, 1987). 
Table 2. Frequency of positive horses (IFAT, $\geq 1: 64$ ) for Toxoplasma gonii antibodies from the Mountain and Coastal regions, Santa Catarina State, Brazil, for analyzed variable and total. 2013.

\begin{tabular}{|c|c|c|c|c|c|c|c|c|}
\hline \multirow{2}{*}{\multicolumn{2}{|c|}{ Variables }} & \multicolumn{2}{|c|}{ Animals } & \multicolumn{2}{|c|}{ Positive $^{1}$} & \multicolumn{2}{|c|}{ Positive $^{2}$} & \multirow[b]{2}{*}{$\mathrm{p}$} \\
\hline & & $\mathrm{n}$ & $\%$ & $\mathrm{n}$ & $\%$ & $\mathrm{n}$ & $\%$ & \\
\hline \multirow{2}{*}{ Region } & Mountain & 311 & 50.6 & 32 & 10.2 & 32 & 50.0 & \multirow{2}{*}{1.0} \\
\hline & Coastal & 304 & 49.4 & 32 & 10.5 & 32 & 50.0 & \\
\hline \multirow{2}{*}{ Sex } & Male & 270 & 43.9 & 28 & 10.4 & 28 & 43.8 & \multirow{2}{*}{1.0} \\
\hline & Female & 345 & 56.1 & 36 & 10.4 & 36 & 56.2 & \\
\hline \multirow{2}{*}{ Breed } & Mixed & 166 & 27.0 & 14 & 8.4 & 14 & 21.9 & \multirow{2}{*}{0.4299} \\
\hline & Pure & 449 & 73.0 & 50 & 11.1 & 50 & 78.1 & \\
\hline \multirow{5}{*}{ Age } & $<6$ months & 04 & 0.7 & 0 & - & 0 & - & \multirow{5}{*}{0.6} \\
\hline & 6-12 months & 11 & 1.8 & 01 & 9.1 & 01 & 1.6 & \\
\hline & $1-5$ years & 197 & 32.0 & 26 & 13.2 & 26 & 40.6 & \\
\hline & $6-10$ years & 227 & 36.9 & 22 & 9.7 & 22 & 34.4 & \\
\hline & $>10$ years & 176 & 28.6 & 15 & 8.5 & 15 & 23.4 & \\
\hline \multirow{10}{*}{$\begin{array}{l}\text { Contact with } \\
\text { animals }\end{array}$} & Dog & 130 & 21.2 & 17 & 13.1 & 17 & 26.5 & \multirow{10}{*}{0.6} \\
\hline & Cat & 07 & 1.1 & 0 & - & 0 & - & \\
\hline & Dog and Cat & 90 & 14.6 & 8 & 8.9 & 8 & 12.5 & \\
\hline & Dog and Bovine & 184 & 29.9 & 18 & 9.8 & 18 & 28.1 & \\
\hline & Dog, Cat and Bovine & 167 & 27.2 & 17 & 10.2 & 17 & 26.5 & \\
\hline & Dog and Pig & 02 & 0.4 & 01 & 50.0 & 01 & 1.6 & \\
\hline & Bovine & 13 & 2.1 & 0 & - & 0 & - & \\
\hline & Equine & 07 & 1.1 & 02 & 28.6 & 02 & 3.2 & \\
\hline & Dog and Chicken & 05 & 0.8 & 01 & 20.0 & 01 & 1.6 & \\
\hline & No Contact & 10 & 1.6 & 0 & - & 0 & - & \\
\hline \multirow{7}{*}{$\begin{array}{l}\text { Reproductive } \\
\text { Disorders }\end{array}$} & Abortion & 21 & 3.4 & 0 & - & 0 & - & \multirow{7}{*}{0.0376} \\
\hline & Stillborn & 01 & 0.2 & 0 & - & 0 & - & \\
\hline & Return Season & 39 & 6.3 & 03 & 7.7 & 03 & 4.7 & \\
\hline & No Disorders & 543 & 88.2 & 57 & 10.5 & 57 & 89.0 & \\
\hline & $\begin{array}{c}\text { Abortion }+ \text { Return } \\
\text { Season }\end{array}$ & 09 & 1.5 & 03 & 33.3 & 03 & 4.7 & \\
\hline & Endometritis & 01 & 0.2 & 0 & - & 0 & - & \\
\hline & $\begin{array}{l}\text { Abortion }+ \text { Return } \\
\text { Season }+ \text { Stillborn }\end{array}$ & 01 & 0.2 & 01 & 100 & 01 & 1.6 & \\
\hline Neurologic & Yes & 03 & 0.5 & 01 & 33.3 & 01 & 1.6 & \multirow{2}{*}{0.2812} \\
\hline Disorders & No & 612 & 99.5 & 63 & 10.3 & 63 & 98.4 & \\
\hline Total & & 615 & 100 & 64 & - & 64 & 100 & \\
\hline
\end{tabular}

Positive1 = Relation among the positive animals within a category and the total of animals of its category.

Positive 2 = Relation among the positive animals within a category and the total of positive animals.

$\mathrm{p}=$ descriptive level of the Fischer exact's test. 


\section{Conclusion}

The occurrence of antibodies against $T$. gondii in horses from the mountain and coastal regions of the State of Santa Catarina, in Brazil, indicates the previous exposure of these animals to the parasite and has implications for animal and public health. No correlation was observed between seropositivity for $T$. gondii and the risk factors analyzed.

Source of Funding

Programa de Apoio à Pesquisa da Universidade do Estado de Santa Catarina - UDESC (Program for Research Support of the State University of Santa Catarina - UDESC).

\section{References}

AGANGA, A. O.; KWANASHIE, G. G.; BELINO, E. D. Toxoplasma antibodies in polo horses of Nigeria. International Journal of Zoonoses, Taiwan, v. 10, n. 2, p. 155-158, dec. 1983.

AL-KHALIDI, N. W.; DUBEY, J. P. Prevalence of Toxoplasma gondii infection in horses. Journal of Parasitology, Lawrence, v. 65, n. 2, p. 331-334, abr. 1979.

BRASIL. Ministério da Agricultura Pecuária e Abastecimento. Equídeos. Brasília: MAPA, 2013. Disponível em: <http://www.agricultura.gov.br/animal/ especies/equideos>. Acesso em: 12 nov. 2013.

CAMARGO, M. E. Introdução às técnicas de imunofluorescência. Revista Brasileira de Patolologia Clínica, São Paulo, v. 10, n. 3, p. 143-171, 1974.

CAMOSSI, L. G.; SILVA, A. V.; LANGONI, H. Inquérito sorológico para toxoplasmose em equinos da região de Botucatu. Arquivo Brasileiro de Medicina Veterinária e Zootecnia, Belo Horizonte, v. 62, n. 2, p. 484-488, mar. 2010.

CASTAGNO, I. Carne de cavalo é negócio de exportação no Paraná. Curitiba: Gazeta do Povo, 2013. Disponível em: <http://agro.gazetadopovo.com.br/noticias/pecuaria/ carne-de-cavalo-e-negocio-de-EXPORTACAO-NOPARANA-2>. Acesso em: 20 maio 2013.

COIRO, C. J.; LANGONI, H.; SILVA, R. C. Epidemiological aspects in the Leptospira spp. and Toxoplasma gondii infection in horses from Botucatu, Sao Paulo, Brazil. Journal of Equine Veterinary Science, Amsterdam, v. 32, n. 10, p. 620-623, may 2012.
DUBEY, J. P.; DESMONTS, G. Serological responses of equids fed Toxoplasma gondii oocysts. Equine Veterinary Journal, Londres, v. 19, n. 4, p. 337-339, jul. 1987.

DUBEY, J. P.; JONES, J. L. Toxoplasma gondii: infection in humans and animals in the United States. Internacional Journal of Parasitology, New York, v. 38, n. 11, p. 12571278, sept. 2008.

DUBEY, J. P.; THULIEZ, P.; ROMAND, S.; KWOK, O. C. H.; SHEN, S. K.; GAMBLE, H. R. Serologic prevalence of Toxoplasma gondii in horses slaughtered for food in North America. Veterinary Parasitology, Amsterdam, v. 86, n. 4, p. 235-238, oct. 1999.

DUBEY, J. P.; THULLIEZ, P. Persistence of tissue cysts in edible tissues of cattle fed Toxoplasma gondii oocysts. American Journal Veterinary Research, Chicago, v. 54, n. 2, p. 270-273, fev. 1993.

EBTESAM, A.; FATMAA, A.; MANAL, E. Seroprevalence of Toxoplasma gondii antibodies in horses at Riyadh city. Journal of Animal and Veterinary Advances, Cairo, v. 13, n. 3, p. 139-143, mar. 2014.

ELBEZ-RUBENSTEIN, A.; AJZENBERG, D.; DARDÉ, M. L.; COHEN, R.; DUMÈTRE, A.; YEAR, H.; GONDON, E.; JANAUDE, J. C.; THULLIEZ, P. Congenital toxoplasmosis and reinfections during pregnancy: case report, strain characterization, and review. The Journal of Infectious Diseases, Oxford, v. 199, n. 2, p. 280-285, jan. 2009.

EVERS, F.; GARCIA, J. L.; NAVARRO, I. T.; ZULPO, D. L.; NINO, B. S. L.; EWALD, M. P. C.; PAGLIARI, S.; ALMEIDA, J. C.; FREIRA, R. L. Diagnóstico e isolamento de Toxoplasma gondii em equídeos de frigoríficos brasileiros. Revista Brasileira de Parasitologia Veterinária, Jaboticabal, v. 22, n. 1, p. 5863, jan. 2013.

FINGER, M. A.; VILLALOBOS, E. M. C.; LARA, M. C. C. S. H.; CUNHA, E. M. S.; BARROS FILHO, I. R.; DECONTO, I.; DORNBUSH, P. T.; ULLMANN, L. S.; BIONDO, A. W. Detection of anti-Toxoplasma gondii antibodies in carthorses in the metropolitan region of Curitiba, Paraná, Brazil. Revista Brasileira de Parasitologia Veterinária, Jaboticabal, v. 22, n. 1, p. 179181, jan. 2013.

GARCIA, J. L.; NAVARRO, I. T.; OGAWA, L.; OLIVEIRA, R. C. Soroprevalência do Toxoplasma gondii, em suínos, bovinos, ovinos e equinos, e sua correlação com humanos, felinos e caninos, oriundos de propriedades rurais do norte do Paraná-Brasil. Ciência Rural, Santa Maria, v. 29, n. 1, p. 91-97, jul. 1999.

GAZETA, G. S.; DUTRA, A. E. A.; NORBERG, A. N.; SERRA-FREIRE, N. M.; SOUZA, W. J. S.; AMORIM, 
M.; LOPES, L. M. S. Frequência de anticorpos antiToxoplasma gondii em soros de equinos no estado do Rio de Janeiro. Revista Brasileira de Parasitologia Veterinária, São Paulo, v. 6, n. 1, p. 87-91, fev. 1997.

GENNARI, S. M.; ESMERINI, P. O.; LOPES, M. G.; SOARES, H. S.; VITALIANO, S. N.; CABRAL, A. D.; PENA, H. F. J.; HORTA, M. C.; CAVALCANTE, P. H.; FORTE, K. P.; VILLALOBOS, E. M. C. Occurrence of antibodies against Toxoplasma gondii and its isolation and genotyping in donkeys, mules, and horses in Brazil. Veterinary Parasitology, Amsterdam, v. 209, n. 1, p. 129132, jan. 2015.

INSTITUTO BRASILEIRO DE GEOGRAFIA E ESTATÍSTICA - IBGE. Banco de dados agregados. Censo Agropecuário de 2012. Brasília: IBGE, 2012. Disponível em: <http://www.sidra.ibge.gov.br/bda/ tabela/protabl.asp $\mathrm{c}=3939 \& \mathrm{z}=\mathrm{t} \& \mathrm{o}=24 \& \mathrm{i}=\mathrm{P}>$. Acesso em: 4 fev. 2013.

JUNQUEIRA, A. C. A.; BRESSAN, M. C.; REBELLO, F. F. P.; FARIA, P. B.; VIEIRA, J. O.; SAVIAN, T. V. Composição centesimal e teor de colesterol na carne de equinos (Equus caballus, Linneaus, 1758) machos e fêmeas agrupados por peso de carcaça. Ciência e Agrotecnologia, Lavras, v. 29, n. 2, p. 362-368, mar. 2005.

KIJLSTRA, A.; JONGERT, E. Toxoplasma-safe meat: close to reality? Trends in Parasitology, Oxford, v. 25, n. 1, p. 18-22, oct. 2009.

KOUAM, M. K.; DIAKOU, A.; KANZOURA, V.; PAPADOPOULOS, E.; GAJADHARA, A. A.; THEODOROPOULOS, G. Seroepidemiological estudy of exposure to Toxoplasma, Leishmania, Echinococcus, and Trichinella in equids in Greece and analysis of risk factors. Veterinary Parasitology, Amsterdam, v. 170, n. 1-2, p. 170-175, may 2010.

LARANJEIRA, N. L.; ISHIZUKA, M. M.; HYAKUTAKI, S. Prevalência da toxoplasmose equina avaliada pela técnica de imunofluorescência indireta no Mato Grosso do Sul. Boletin de la Oficina Sanitária Panamericana, Washington, v. 99, n. 2, p. 158-162, ago. 1985.

LING, C. W.; WAN, P. D. A report of investigations of antibodies to Toxoplasma gondii in the horse and mule in Sichuan Province. Journal of Veterinary Science and Technology, Suwon, v. 4, n. 1, p. 32-34, 1984.

LOPES, A. P.; SOUSA, S.; DUBEY, J. P.; RIBEIRO, A. J.; SILVESGTRE, R.; COTOVIO, M.; SCHALLIG, H. D. F. H.; CARDOSO, L.; CORDEIRO-DA-SILVA, A. Prevalence of antibodies to Leishmania infantum and Toxoplasma gondii in horses from the north of Portugal.
Parasites \& Vectors, Londres, v. 6, n. 1, p. 178-184, jun. 2013.

MACRUZ, R.; LENCI, O.; ISHIZUKA. M. M.; OMAR, M.; CUNHA, R. A. F. Toxoplasmose em equinos PSI. Estudo sorológico. Revista da Faculdade de Medicina Veterinária e Zootecnia da Universidade de São Paulo, São Paulo, v. 12, n. 1, p. 277-282, ago. 1975.

MARQUES, L. C.; COSTA, A. J.; LOPES, C. W. G.; LACERDA NETO, J. C. Experimental toxoplasmosis in pregnant mares: clinical signs, parasitemia and immunological observations. Semina: Ciências Agrárias, Londrina, v. 19, n. 1, p. 45-49, mar. 1998.

MATSUO, K.; KAMAI, R.; UETSU, H.; GOTO, H.; TAKASHIMA, Y.; NAGAMUNE, K. Seroprevalence of Toxoplasma gondii infection in cattle, horses, pigs, and chickens in Japan. Parasitology International, Amsterdam, v. 63, n. 4, p. 638-639, oct. 2014.

MENDONÇA, A. O.; CERQUEIRA, E. J. L.; ARAÚJO, W. N.; MORAES-SILVA, E.; SHIMABUKURO, F. H.; SARKIS, D. T.; SHERLOCK, I.; LANGONI, H. Inquérito sorológico para toxoplasmose em equídeos procedentes de duas regiões do estado da Bahia, Brasil. Semina: Ciências Agrárias, Londrina, v. 22, n. 2, p. $115-$ 118, jul. 2001.

MIAO, Q.; WANG, X.; SHE, L. N.; FAN, Y. T.; YUAN, F. Z.; YANG, J. F.; ZHU, X. Q.; ZOU, F. C. Seroprevalence of Toxoplasma gondii in horses and donkeys in yunnan province, Southestern China. Parasites \& Vectors, Londres, v. 6, n. 168, p. 1-5, jun. 2013.

OLIVEIRA FILHO, R. B.; MALTA, K. C.; OLIVEIRA, J. M. B.; ALBUQUERQUE, P. P. F.; MOTA, R. A. SANTANA, V. L. A.; ALVES, L. C.; PINHEIRO JUNIOR, J. W. Epidemiological situation of Toxoplasma gondii infection in equids from Brejo Paraibano microregion, Brazil. Pesquisa Veterinária Brasileira, São Paulo, v. 32, n. 10, p. 995-1000, oct. 2012.

ORGANIZACION PANAMERICANA DE LA SALUD - OPAS. Bioestatisica: procedimientos para estudios de prevalencia por muestreo. Buenos Aires: Organizacion Panamericana de la Salud, 1979. n. 18, 35 p.

POMARES, C.; AJZENBERG, D.; BORNARD, L.; BERNARDIN, G.; HASSEINE, L.; DARDÉ, M. L.; MARTY, P. Toxoplasmosis and horse meat, France. Emerging infectious Diseases Journal, Atlanta, v. 17, n. 7, p. 1327-1328, jul. 2011.

SILVA, R. A. M. S. Antibodies to Toxoplasma gondii in horses from Pantanal, Brazil. Veterinária e Zootecnia, Botucatu, v. 12, n. 1-2, p. 20-24, set. 2005. 
TASSI, P. Toxoplasma gondii infection in horses. A review. Parassitologia, Roma, v. 49, n. 1-2, p. 7-15, jun. 2007.

TENTER, A. M.; HACKEROT, A. R.; WEISS, L. M. Toxoplasma gondii: from animals to humans. International Journal for Parasitology, New York, v. 30, n. 12, p. 1271-1258, nov. 2000.
VIDOTTO, O.; KANO, F. S.; FREIRE, R. L.; MITSUKA, R.; OGAWA, L.; BONESI, G.; NAVARRO, I. T.; FRANSISCONI, F. S. G. Ocorrência de anticorpos antiToxoplasma gondii em equinos procedentes de quatro Estados (SP, PR, MS e MT) abatidos em Apucarana, PR. Semina: Ciências Agrárias, Londrina, v. 18, n. 1, p. 9-13, mar. 1997. 
